\title{
THE CONSEQUENCES OF HUMANITARIAN PEACEKEEPING IN AFRICA
}

\author{
Prof Rialize Ferreira \\ Department of Sociology, University of South Africa
}

\begin{abstract}
Owing to the changing nature of international conflict, the 1990s witnessed a growing need for humanitarian peacekeeping operations, especially in Africa. The reluctance of the United Nations to be involved in peacekeeping operations in Africa compelled South Africa to take part in peacekeeping to assist neighbouring conflictridden states. There is, however, a discrepancy between the conceptualisation and application of peacekeeping and peace-enforcement operations. This notion is manifest in the changing nature of post-Cold War conflicts and requisite strategies, doctrines and operational procedures to execute these operations. A shift in South African defence policy was necessary to accommodate an expanded mandate to make provision for African peacekeeping missions. These humanitarian missions unfortunately also have unintended, latent consequences for the host populations, which can harm the peace operations as such.

The aim of this article is to investigate traditional peacekeeping shifting to peace-building as a manifest, intended consequence and the way in which unintended, latent consequences of peacekeeping come about.
\end{abstract}

\section{Introduction}

Since the end of the Cold War in 1989 the changing nature of international politics and subsequent conflicts, being mostly intra-state, as well as increasing demands for peacekeeping during the 1990s, have put a huge burden on the capabilities and resources of not only the United Nations (UN), but also participating countries. The unprecedented demand for peacekeepers was complicated by the changing role they would have to play. Peacekeepers were not expected to intervene in hostile conflicts, which is a non-consensual function for them to fulfil. Humanitarian peacekeeping refers to monitoring and protecting of human rights and security and the alleviation of human suffering in host countries. It is commonly known that UN peacekeepers failed in many instances to meet these daunting 
challenges, especially in Africa where the scope and intensity of violence during the 1990s were great. According to the Special Report on Peacekeeping in Africa the continent was plagued by 16 armed conflicts in 1999 alone (Docking 2001:1). Seven of these armed conflicts each reflected battle-related deaths of more than a 1000 .

During 2001 the Brahimi Report, seen as "the most important document on peacekeeping ever written" (US Institute for Peace 2001:1), compiled a systematic and comprehensive report to identify the technical problems of UN peacekeeping missions, as well as those within the Department of Peacekeeping Operations (DPKO) of the UN. It was established that the DPKO was understaffed and the administrative budget proved to be insufficient. International political support for the growing need for peacekeepers was lacking, as was funding from member states, especially the USA. What the Brahimi Report failed to address was the lack of political will of member states to contribute to UN peacekeeping. It was found that the conflict in the Democratic Republic of Congo (DRC) was the most protracted war in Africa. Since 1998 this conflict has involved the armed forces of nine different states and approximately nine rebel groups (US Institute for Peace 2001:1). The UN and Western countries saw this complexity, together with the vast territory it covered, as a key reason not to get involved, shifting the burden exclusively onto developing countries with limited resources.

According to Docking (2001:3) the "lack of political will" shown by Western countries is the major hindrance of deployment and success of the UN in Africa and elsewhere. Western countries are reluctant to participate because few foreign leaders will risk the loss of soldiers in poorly understood (African) countries where they do not have perceived economic or strategic interests. They no longer wish to spend billions on costly military interventions each time conflict erupts in Africa. These circumstances compel South Africa (SA) to contribute to peacekeeping operations, since the notion exists that Africa should look after its own and solve its own problems. This would require a broader, expanded policy mandate for the South African Defence Force (SANDF) to participate in African peacekeeping operations, since SA should also protect itself from the spill-over effects of regional conflicts.

With conflicts still simmering in countries such as the DRC, Burundi, Eritrea/Ethiopia, Nigeria and Sudan, it is unimaginable that peacekeeping will diminish. The long-term effects these conflagrations will have on development on the African continent are multi-fold. The peacekeeping missions will inevitably have manifest or positive, intended, as well as latent or negative, unintended consequences for the host populations of the different conflict-ridden countries involved. The different consequences of or contributions to peacekeeping are based 
on a functionalist theoretical perspective, or systems approach, which underlies the notion of order and stability in societies.

\section{The shift in defence policy}

The changing nature of international peace missions began forcing governments to reconsider their policies on conflict prevention and participation in peace missions. Some shifts placed a greater emphasis on the development of sub-regional organisations, such as the Southern African Development Community (SADC) and the African Union (AU) to manage complex peace missions and the increased focus on peace-building strategies for war-torn countries (Williams 1999:153). Irrespective of the regional emphasis, most countries participating in peace missions usually also have national interests for doing so.

After the first democratic elections in 1994 the new South African Constitution (1996), the White Paper on Defence (1996), the Defence Review (1998) and the White Papers on Intelligence (1995) and on Participation in International Peace Missions (1999) were formulated and promulgated. National security was now regarded in comprehensive terms to include military, political, economic, social, technological and environmental dimensions. Apart from the traditional concerns with defence and state, policies were infused with human security principles referring to those basic principles and core values associated with and essential to the quality of life of people, freedom, justice, prosperity and development for all South Africans.

In the absence of imminent war in the region, a new security environment emerged and a redefinition of security became necessary. After 1994 debates on peacekeeping developed steadily in SA and major challenges confronted planners of future peace operations. Initially SA was wary of participating in peacekeeping, because of regional insecurities regarding its hegemonic profile in Africa and not wanting to throw its weight around. This political sensitivity and novelty of peacekeeping for the South African armed forces served as deterrents to contribute forces. Public and private objections to proposals of peacekeeping reflected concerns and the notion was that SA would attempt to use its diplomatic and moral muscle to resolve crises before committing troops to a conflict area (Williams 1999:156). Some of the challenges were to establish the type of force required for peacekeeping, the training of such a force and the development of a doctrine for use by South African armed forces (Williams 1996:1).

New policy documents had to be formulated to provide for expanded mandates to participate in humanitarian peacekeeping in Africa. The Departments of Foreign Affairs and Defence embarked upon the drafting of a White Paper on Participation 
in Peace Missions in 1997 in the absence of definite guidelines and a well-defined mandate for dealing with requests to participate in specific peace missions to intervene in a more holistic approach, relating to human security priorities (Kent \& Malan 2003:1). Peace missions were put within a broad framework with peacebuilding as the main focus, emphasising that military participation in peace missions is only one tool available to engage in Africa. The challenges to be met were finding methods to communicate, resource and implement the good intentions of the White Paper promulgated in 1999. Through accepting South Africa's peace-building role, the White paper stressed the partial responsibility for stability in Africa (Cilliers \& Mills 1999:5).

A major challenge was to redefine the roles and tasks of the SANDF to participate in peacekeeping missions in Africa instead of only fulfilling the traditional roles of conventional warfare and protection against external aggression. In the new security environment the military had to be reconfigured for a wide variety of humanitarian tasks, such as disaster relief and peacekeeping missions. However, the Defence Review of 1998 viewed peacekeeping as a secondary function and fulfilling secondary roles in the military became a point of dispute and ambivalence for professional soldiers who were specifically trained in conventional warfare. The feeling was that the SANDF was simply "not prepared, structured and trained for law and order tasks" (Pepani 1999:96). Simultaneously, the notion also existed that multi-role and skills-based training had become essential, to include peacekeeping.

Ngoma (2004:101) was of the opinion that the balancing of the needs of the defence sector with other more humane social needs was important to ensure the appropriate utilisation of scarce resources. By taking the expanded roles of human security into account to provide education, health services and communication networks in remote areas, the defence sector did not have to degrade its primary roles by taking on additional secondary roles. The role of the military and security services had to be re-examined to establish to what extent the limited resources were directed at the necessity to fulfil the secondary roles as well, instead of only the primary ones. Pre-deployment training was necessary before any specific deployment and was mission-oriented, because it would enhance the execution of missions and provided flexibility to change swiftly and easily between missions. The military and security services also had to ensure that they remained aligned to their primary roles of providing defence and security to the state and its people (Ngoma 2004:101). Therefore, it became necessary to revise the Defence White Paper (1996) and the Defence Review (1998) to include additional secondary roles for members of the defence force and security services. South Africa had to prove its readiness to 
participate in international peacekeeping missions. In fact, the Defence Review (1998) already stated that:

"South Africa could contribute ground forces of up to one battalion group strength to any particular operation, whilst also ensuring that the SA Army's Rapid Deployment Ground Force and two battalion groups would be prepared for participation in peace missions" (Williams 1999:166).

This regulation, however, would prove to be insufficient because peace missions in Africa required many more troops than those it specified. To deploy more troops an expanded mandate was needed in the form of an updated Defence White Paper and Review (which began in 2003 and is said to be tabled in parliament November 2009), because political conflict in Africa was not confined within national borders. Regional instabilities can easily spill over into SA and have a negative effect on non-military development, such as the spreading of disease and movement of refugees.

A shift in defence policy had to accommodate a broader, more inclusive mandate and roles for humanitarian peacekeeping operations in African countries such as Eritrea, Ethiopia, the DRC, Burundi and Sudan. Missions were to be mandated and authorised by the UN, but SA would only participate when it had national interests for doing so and when a real threat might cause long-term instability in the region. The notion was that domestic peace and stability would not be achieved in a context of regional instability where famine, political repression and violent conflict and natural disasters were prevalent. Therefore, through peacekeeping South Africa wanted to pursue a collective, mutually beneficial security environment. This expanded mandate required the White Paper on Participation in International Peace Missions (1999), which is a ground-breaking document outlining the national interests and philosophy on conflict resolution, to be updated. This was necessary to accommodate the need to assign peacekeeping a proper place in terms of the roles and functions of the SANDF as a visible element of the foreign policy to enable collective security in Africa. This White Paper put peace missions within a broad peace-building scenario and reflected South Africa's approach to Africa in general (Cilliers \& Mills 1999:5; 156-157).

The Departments of Defence and Foreign Affairs embarked upon updating the existing White Paper on Participation in International Peace Missions (1999) in 2006 by providing collaborative inputs from stakeholders in civil society, such as the joint Standing Committee on Defence in Parliament, representatives from Foreign Affairs, defence and security personnel. This involvement caused Parliament to reconsider funding requirements for development and peacekeeping in African regions. Currently, in 2008, the review of the 1999 policy on peace missions is still 
under way. This revised policy is considered to be a necessity to accommodate participation in peace-building and reconstruction efforts in Burundi, the Central African Republic, the DRC, Somalia, Rwanda, Eritrea/Ethiopia, Liberia, Sierra Leone, Sudan and Cote D'Ivoire (Van der Merwe 2008:2).

However, according to Williams (1996:60), it is in the challenge of policy changes that planners of peace operations ignore the practical "nuts and bolts". These include issues encountered in the field, which can be avoided through judicious planning and preparation for anticipated, intended future development. These potential problems, also seen as latent, unintended negative consequences, can range from macrocosmic to microcosmic levels:

- At the macrocosmic level peace processes can be hampered by domestic political pressure, inadequate policy formulation, absence of political will to participate and insufficient international authority supporting the mission, as well as the existence of irreconcilable ethnic differences between the belligerents themselves.

- At the microcosmic level peace operations can fail because of practical factors ranging from operational inadequacies to inconsistencies in the rules of engagement, poor soldier discipline, poor installation security, inadequate intelligence and training, as well as inadequate negotiation skills (Williams 1996:61).

It is clear that an update of the policy on peace missions must provide for new experiences gathered in these missions. According to Kent (2005:85) the achievement of military objectives and a secure environment are no longer a guarantee for self-sustaining peace. It is rather the re-establishment of the "rule of law, good governance, reconciliation, reconstruction and development programmes" that is regarded as prerequisites for peace and security.

\section{Peacekeeping in Africa}

According to Cilliers (1999: 138) the concept of peacekeeping was designed to deal with interstate conflict and not with intra-state conflict. It is based on the assumption that conflicting states have agreed to international assistance to help them live orderly and peacefully and regain stability. However, no major African peacekeeping operation was of this nature, since direct conflict between African states has been a scarce phenomenon. Almost all African conflicts that needed some peacekeeping efforts have been within the borders of specific countries, thus intrastate. "An important reason for this feature is the permeability of African state borders and the weakness of African states themselves" (Cilliers 1999:138). This reason does not detract from the fact that almost all internal conflicts had regional aspects, because neighbouring countries have involved themselves in the internal affairs of others and allowed their territory to be used by rebel groups. Cross-border 
actions do take place (e.g. Rwanda and the DRC) because countries are simply incapable of controlling their borders. Neither did peacekeeping missions and peacekeepers have the consent of the state in conflict, which is usually the case in traditional peacekeeping missions. In Africa peacekeepers do not have the relatively straightforward task of merely policing agreements between states. They are plunged into intractable problems and called upon to recreate collapsing states, intervene in vicious civil wars and enforce, if needed, peace settlements (e.g. in Burundi) between conflicting parties whose commitment to peace is uncertain (Cilliers 1999:139).

According to Ngoma (2005:2) there are three stages of peacekeeping. Firstly, when unarmed or lightly armed troops intercede between warring parties it is called first-generation peacekeeping. To remain neutral is not easy, especially when one side is guilty of brutal human rights abuses. Second-generation peacekeeping improves upon the first model by undertaking more complex functions, such as policing responsibilities. All belligerents will give comprehensive consent to the mission. Support structures will consolidate peace by disarming the warring parties, destroying weapons, repatriating refugees, monitoring elections and promoting formal and informal processes of political participation. These pertinent requirements for a peaceful environment show the magnitude of the task at hand (Ngoma 2005:2). Third-generation peacekeeping is designed to resolve major difficulties, such as guaranteeing the safe passage of humanitarian assistance, helping displaced persons and stopping the killing of ordinary citizens by more forceful measures. These are followed by peace-enforcement missions to ensure forcibly that whatever agreements were reached in prior negotiations will be respected.

"Peace operations" is an all-encompassing term for peacemaking, peacekeeping and peace enforcement. In this article the focus is specifically on peacekeeping operations, which involve "the use of military forces to maintain a negotiated truce and facilitate a diplomatic/political resolution to a specific conflict" (Williams 1996:61). These operations monitor cease-fires, arms control, disengagement and demobilisation under the auspices of, for example, the UN or the AU. Peacekeeping operations are known by their emphasis on restraint and a self-defensive posture and usually presuppose the existence of a cease-fire, while the political objective is of the utmost importance.

In $\mathrm{SA}$ it is known that there is a grey area between the conceptualisation and application of peacekeeping and peace enforcement. This was proven in the Burundian case when the use of military force was necessary to secure an end to hostilities to find a political and diplomatic solution to the conflict. There was little 
distinction between peacekeeping and peace-enforcement operations because a cease-fire was not yet in existence when peacekeepers were deployed. Therefore offensive tactics and weaponry had to be used to accomplish a cease-fire eventually. South African peacekeepers had to assist in negotiating a truce and protect 150 VIPs who came to Burundi for political negotiations. This positive action on the part of SA can be seen as a manifest consequence of peacekeeping in the changing postCold War era.

Swigert (2004:2) is also of the opinion that the past two decades saw changes in peacekeeping, as the normative patrolling of the static cease-fire line is now the exception. Peacekeepers are sometimes charged with more responsibilities, to protect not only themselves, but also the local communities. The tendency is to expect more from $(\mathrm{UN})$ peacekeepers than they are mandated to do. The ultimate end of the spectrum of peace operations is to perform challenging tasks, even including warfare, for which they are not equipped or trained. A military force would be better equipped. In the case of Liberia in 2003 the regional Economic Organisation of West African States (ECOWAS) intervened. The AU has also successfully intervened in peace missions, with the encouragement of the USA in the case of Burundi in 2003. The AU has also gone to Darfur in Sudan with troops to protect cease-fire monitors. The willingness of African states, such as South Africa, to contribute to peacekeeping in neighbouring war-torn states is commendable. After the publication of the Brahimi Report in 2000 the $\mathrm{UN}$ is now willing to reform its peace missions to participate with African armed forces to improve their capabilities (Swigert 2004:2).

Although participation in peacekeeping is commendable, it is by nature a costly business. The extent of peacekeeping in Africa is not limited only by political will, but by the availability of funds as well. The AU experience has been that even a relatively small and logistically easy operation undertaken by unarmed observer missions was so "costly that it was not able to finance them from its own budget" (De Coning 2004:4). South Africa experiences a similar position since the funds for peacekeeping have to come from the existing primary role budget, while no extra funds are made available for secondary roles. "Lean peacekeeping" will require peacekeepers to "make do" with available resources (Cilliers \& Mills 1999:4). At its height, the African mission in Burundi is the largest ever undertaken by the AU, with 3335 personnel deployed during 2004. An operational budget of US \$110 million per year was needed. Such an expense is exorbitant in the African sense and will determine the kind of peacekeeping mission the $\mathrm{AU}$ is prepared to undertake in future. 
The reality is that African peacekeeping will remain underfunded. Therefore, the only viable long-term missions in Africa will be UN peace operations. African peace operations will have to be funded by the international community, such as member states of the UN and the USA. In the long term AU peacekeeping will only have to focus on short-term stabilisation missions such as the one in Liberia, which can be undertaken by sub-regional organisations or coalitions such as ECOWAS (De Coning 2004:5).

Some analysts recommend that the regional SADC participates in peacekeeping by using the SADC regional standby arrangement for the African Standby Force. The development of such a force "is a significant achievement because it provides Africa with a common policy framework for peacekeeping capacity building" (De Coning 2004:4). It must be deployed as a well-trained, disciplined force for peacekeeping operations and can be integrated with other mission participants, especially relief and reconstruction missions. In a common SADC peacekeeping system South Africa will have to play a major role, considering its hegemonic influence. Such a system will benefit from South Africa's influence, resources and peacemaking abilities and initiatives. However, it is possible that it can unintentionally become subservient to South Africa's national interests (De Coning 2004:7).

According to Williams (1996:66) it should be acknowledged that the training for peacekeeping and peace enforcement differs. Peacekeeping requires training in the form of mine or booby-trap handling, patrolling, checkpoint operations, media liaison, supervision of cease-fires, maintenance of law and order and the rebuilding of infrastructure, which is especially important in Africa. Peace enforcement, on the other hand, involves enforcement of UN sanctions, protection of minority rights, humanitarian relief efforts, separation and disarming of warring factions and the restoration of law and order. Given the experience the SANDF has in internal policing operations within South African city suburbs, it has accumulated knowledge regarding peace enforcement to apply in future peace operations in Africa. SANDF peacekeeping training is mission-specific and makes provision for complex, integrated, multifaceted operations aimed at supporting and facilitating comprehensive peace agreements. In addition, the focus of peace operations is shifting gradually from peacekeeping to peace-building.

The consequences of interventions related to peacekeeping, peace-building, and peace enforcement missions are not always considered in the changing post-Cold War era. Manifest intended or positive and latent unintended or negative consequences of peacekeeping will have to be considered in the combination of policy structures and procedures, which are foreseen to regulate and control 
peacekeeping systems. The changes in the role and scope of peace operations over the last decade exposed a new range of potential unintended consequences for the host society as well as for the peace operation itself (Aoi et al 2007:2).

\section{Intended and unintended consequences of peacekeeping}

Traditional peacekeeping, usually by the UN, was mandated to observe and control cease-fire or peace agreements intending to have neutral effects and not to have any impact on future directions of the peace process and status quo. Peacekeeping has, however, changed in post-Cold War times, having an extended focus on peace-building, intending to bring positive changes to the population of the host country, which is usually involved in an intra-state conflict and not interstate as before. Despite these positive mandates, unintended, negative consequences do prevail. According to Aoi et al (2007:1) the phenomenon of unintended latent consequences of peace operations is poorly understood and conceptualised. The unintended latent consequences of a rapid external intervention on an already fragile host society and economy can weaken the ability of a successful peace operation and its intended objectives. The contention is that some unintended consequences can harm the very peace operation, since conflicts tend to be prolonged with escalations and de-escalations leading to severe casualties and infrastructural damage, which needs to be rebuilt during the peace-building efforts (Twum-Danso 2003:2).

According to Aoi et al (2007:2) "no intervention in a complex system like a human society can have only one effect. Complex systems are dynamic and respond to interventions in a nonlinear fashion". Therefore, systems can respond to interventions in both an anticipated and unanticipated manner. The latter is called an unintended consequence as a natural outcome of a dynamic system. This means that despite best efforts to have positive, intended consequences in an intervention, negative unintended consequences will also occur. These could also be regarded as dysfunctions. Negative, unintended consequences are latent and unexpected because they are harmful to the local populations, to the notion of international peace interventions as such because their effectiveness is hampered, as well as harmful to the organisation that mandates and deploys the peace operations (Aoi et al 2007:3). There are also some unintended consequences far beyond specific peace operations, e.g. violence, sexual exploitation and abuse by UN peacekeepers of those they are supposed to protect. These negative consequences have undermined the credibility of the UN, the Secretary-General and peace operations as an international conflict management tool (Aoi et al 2007:4).

However, the fact that unintended latent consequences occur does not render futile the mandating, planning and managing of peace processes. Unintended consequences are predictable side-effects of such processes and they should be 
catered for in planning and managing. The fact that these consequences do not receive much attention could be ascribed to the preoccupation of planners and practitioners with reaching intended consequences of peace operations, e.g. rebuilding destroyed infrastructure, protecting human rights and alleviating suffering. When measuring the success of peace operations, the mandates they were tasked with are explicitly focussed upon. Peace operations are expected to ensure positive outcomes such as promoting stability and durable peace, as well as rebuilding and developing host populations to uphold democracy and human rights (Aoi et al 2007:4).

Peace operations may, however, fail to deliver the intended good results, as unintended negative incidents are caused by a few "bad apples" who, for example, act outside the norm by committing atrocities such as rape and sexual abuses, which are regarded as part of the non-linear and dynamic behaviour of complex systems and a systemic consequence of peace operations (Aoi et al 2007:5). However, peacekeepers are still expected to abide by the laws and customs of the host society. They should be duty-bound, professional and support human rights to the benefit of the host populations and the mission itself (Kent 2005:86).

Aoi et al (2007:6) refer to examples of unintended consequences such as sexual abuse and violence, gender abuse, distortions of the local economy, impact on host systems, on humanitarian activities, on civil-military coordination, on troopcontributing countries, and the legal position of the $\mathrm{UN}$ and institutional response to unintended consequences by the UN and others. This article grouped major findings of unintended consequences under the topics: permissive environment, impact on local economy, impact on local civil service, change in gender roles and impact on troop-contributing countries. These latent unintended, negative consequences are discussed below:

Permissive environment refers to the breakdown of law and order, socioeconomic infrastructure and socio-cultural norms. Post-conflict situations, in which most peace operations operate, can create fertile ground for unintended consequences to occur. Natural checks and balances are usually absent. The absence of these systems affords little protection to civilians against violence and sexual abuse (Kent 2005:86). According to Aoi et al (2007:6) it is often a conscious strategy to demoralise the opposing population in a conflict by committing gender and sexual violence against them. There is the problem that such violence can be institutionalised in post-conflict states when conditions remain favourable for violence to occur. Jordan (2004:1) reports that while humanitarian interventions bring money, goodwill and many relief workers, they also bring the practice of 
prostitution and sexual abuse. This is referred to as the darker side of peacekeeping and nation-building.

Kent (2005:87) refers to extreme poverty, lack of economic activity and opportunity and the loss of family members and community support networks as conditions accounting for the vulnerability of girls and women to sexual abuse by local men, as well as international peacekeepers, in exchange for food, money and shelter. These acts damage the credibility of the specific mission and are also conducive to human trafficking. However, the fact that humanitarian workers and peacekeepers are perpetrators of sexual abuse and violence is not a new concept and its gravity cannot be ignored (Kent 2005:87). Peacekeeping operations are also remembered for the children conceived and left behind. These babies and mothers are left without support or provision for the future. Despite clear codes of conduct by the UN, these abuses continue without fear of punishment by the perpetrators as a result of limited remedial action. According to Jordan (2004:1) it is "outrageous that the very same people who are there to protect these women and girls are using their position and exploiting them instead - and they are getting away with it". Sexual violence is regarded with a pervasive air of impunity. Violence against women is generally not prosecuted in the peacekeeper's homeland and certainly not in a chaotic post-conflict zone (Jordan 2004:3).

The impact of the local economy: The deployment of thousands of peacekeepers, police and humanitarian aid civilians has various effects on the host society. These people distort the local economy by establishing a dual economy - one for the peacekeepers and another for the local population. The degree of poverty of the local population will determine the level of impact the peacekeepers will have upon the host society. The negative effects can be an increase in salary disparities and unequal living standards, as well as exploitation of all kinds, while the positive impacts can be job creation for the local communities by increasing a demand for certain commodities used by the international peacekeepers. This economic stimulation is only temporary and cannot be sustained, since the deployment is temporary. However, it could give a false sense of relief to the local population (Aoi et al 2007:7; Jordan 2004:1).

Impact on the local civil service: The dual economic system has an effect on the host public sector in the sense that it not only has a negative effect, but also builds the capacity of the public sector and supports the extension of state control in the host state. Another unintended consequence can be that the inflow of considerable budgetary assistance can result in an increase in corruption by state officials (Aoi et al 2007:8). 
Change in gender roles: In many societies the positions of woman are traditionally subordinate to those of men. They are subjected to gender-based discrimination at home as well as in public and with little control over their own sexuality some trade themselves for food, money and shelter (Kent 2005:87). Notwithstanding, one of the intended consequences of peace-building programmes is the empowerment of women to play a bigger role in society. There are, however, also negative latent effects of women's empowerment, since it invites resentment from their families and society because of their newly gained independence (Aoi et al 2007:9). This can lead to domestic violence in very traditional, cultural societies. It can also lead to role shifting in families by mothers to grandmothers and even to older children where woman assume self-confident and independent roles instead of being subordinate to a patriarchal society.

The impact on troop-contributing countries: Contributions to peace missions give rise to opportunities as well as financial, social and political costs, which again lead to unintended consequences. There is a conception that developing countries contribute troops to peacekeeping since it is a financial opportunity for both the country or the military institution and the individual troops. It is also known that corruption and manipulation occurred in the appointment of high positions to earn higher salaries. In addition, funds coming from the UN to reimburse countries for peacekeeping are sometimes misappropriated (Aoi et al 2007:9).

Participation in peacekeeping is not without danger, even when peacekeepers are to be respected for their neutral and impartial status. In August 2006, for example, two AU peacekeepers were killed in the Darfur region of Sudan by rebel groups. This caused an international outcry against a violation of international law (Jooma 2006:1). This incident relates to the issue of rules of engagement. According to Williams (1996:66) rules of engagement can also cause unintended consequences. These rules are necessary to both the political and operational success of an operation, but indiscriminate or uneven application of force can alienate the host population. It can also lead to attacks on peacekeepers by belligerents. Acts such as these will be a political embarrassment for the troop-contributing country and discredit the peace operation itself.

The issue of integrating unintended consequences into the planning and management of peace operations requires accountability. Authority and the issue of accountability are important elements and refer to the control of the mission. This control relates to the management of behaviour of individuals and covers unintended consequences such as sexual exploitation and abuse, corruption and theft in UN peace operations, which are not initially anticipated or expected. It is usually seen as a once-off incident due to lack of consciousness and institutional preparedness to 
identify the problem. Therefore, unintended consequences have to be included in the planning of a peace operation as part of the natural feedback cycle of complex systems (Aoi et al 2007:10). This will improve the overall effectiveness of the operation. However, since the system is dynamic, it will still be difficult to anticipate all latent unintended consequences to ensure accountability throughout the mission by significantly reducing obvious negative consequences.

Negative effects can be monitored and have to be detected at the earliest opportunity. According to Aoi et al (2007:12) managing unintended consequences in peace operations requires purposefully interacting with the system "with the aim of continuously adjusting our actions to the feedback generated by the system with a view to minimising any negative unintended consequences our interventions may have caused". In containing and managing unintended consequences, the focus is thus on the system feedback through institutionalised monitoring and evaluating mechanisms by constantly adjusting programmes or initiating new actions. The goal is to improve the mechanisms and it must be remembered that the misconduct of a few should not undermine the contributions of many (Kent 2005: 91).

According to Aoi et al $(2007: 14)$ models of accountability refer to two separate potential mechanisms, the delegation and participatory models. Firstly, power is delegated to specific individuals or institutions, making them accountable to those who delegate the power to them, e.g. when the UN reports to the member states and the UN Security Council. Secondly, in the participatory model those in power are accountable to individuals in the polity, e.g. the UN's actions are made accountable to the host population in peacekeeping operations. It would be ideal if a peace operation could establish a balance between these two models of accountability in order to develop meaningful accountability towards and by the host population. The host population constitutes the institutions and civil society and in post-conflict situations these official institutions will undergo considerable change to ensure broad representation of popular will and opinion.

Control over missions rests ultimately with the legal authority of the troopcontributing state, in this case South Africa. It has to control criminal and disciplinary issues concerning troops. The contributing country is responsible for upholding international law and human rights, as well as ensuring that criminal and disciplinary accountability are controlled.

Apart from attending to unintended consequences encountered in peacekeeping missions, some of the major challenges facing the Department of Defence and the SANDF are to reconsider the issue of the primary function in line with secondary functions, to balance the decreasing budget with the requirements of peacekeeping, to improve the skills of SANDF members to participate in humanitarian tasks and to 
integrate newly acquired weapon systems of the Strategic Defence Package into the force design to ensure eventual collective security in Africa (Le Roux 2005:264).

\section{Conclusion}

With (or without) the necessary policy documents in place, South Africa seems to be coping with the challenges of humanitarian peacekeeping and peace-building in Africa. Its role in peace missions is regarded as invaluable, since ending conflicts is an important goal of South Africa's foreign policy to prevent the spill-over of conflict into South Africa itself. Unfortunately, unintended consequences of peace missions are a definite part of dynamic complex systems, and will occur most of the time.

"Post-conflict environments offer the opportunity to address economic, political and social marginalisation by ensuring institutions and legislations are reconstructed in a non-discriminatory manner" (Kent 2005:91). There is unfortunately a time lag between the implementation of the agenda and reaping the rewards thereof. Until the rule of law is established and institutions are in place to assist them, the host population remains vulnerable and unintended consequences could occur. It is thus easy for prostitution and child abuse to flourish in mission areas, also called permissive environments, in the absence of other economic opportunities for women and girls. This problem gets worse as a result of gender discrimination and unequal power dynamics. Poverty, starvation and previous exposure to violence encourage women to trade sexual favours for material gain in order to survive.

Troop-contributing countries, such as South Africa, will have to shape the environment by reaching intended goals through restoring peace and building new infrastructure to alleviate human suffering and pursue sustainable social development. The UN and the AU will have to bring to justice perpetrators of abuse; however difficult it may be, they must be held accountable for their actions. The misconduct of a few can jeopardise the peace mission itself and this must be prevented by timely planning and management of troops. It is important that the services intended to benefit the host populations do not become tools of exploitation (Kent 2005:87). However, it must always be kept in mind that the peacekeepers are faced with real challenges, such as keeping an uneasy peace, often having ambiguous mandates and being away from their families for months with limited leave and recreational facilities.

The purpose of the work by Aoi et al (2007) was to contribute to the improvements of peace operations. The notion was that the aspect of unintended consequences needs to be better understood. Unintended consequences can be 
manifest positive or latent negative or even neutral. Negative unintended consequences are most harmful to the host societies that peace operations are intended to benefit. The focus was explicitly on how unintended consequences come about and how ways to counteract such potential negative circumstances can be improved. To enhance understanding of unintended consequences of peace operations a culture of accountability should be instituted and anticipate unintended consequences as part of all planning cycles to eventually monitor, prevent and manage negative side-effects of humanitarian peace operations. However, to learn lessons from both failures and successes to undertake better peace operations in the long term does not contribute much if the original short term conflict resolution was not well-defined and accomplished, eg. the 1993 Somali case, which led to even more unintended consequences and loss of lives of 18 US Army Rangers in the streets of Mogadishu. The contention is to prevent side-effects and if there is no peace to keep like in Somalia, peacekeepers should not be there at all.

It is clear that unintended consequences are important to understand and can be regarded as a neglected topic in peacekeeping missions. Some are morally and ethically unacceptable and can impede upon the mission's capacity to achieve its mandate. The value of peace operations can be questioned and the troopcontributing countries and institutions such as the UN and AU can be brought into disrepute, while some negative consequences are major incentives for reform and greater accountability within international institutions.

Unintended, negative consequences are therefore regarded as natural consequences of the dynamic nature of complex systems. It is important to recognise and anticipate these consequences in order to make provision to prevent, contain and manage them proactively through institutional mechanisms on a daily basis to build eventual peace in war-torn African countries. Without order and stability there will only be conflict, poverty and no development and growth in Africa.

\section{LIST OF SOURCES}

Aoi, C., De Coning, C. \& Thaku, R. 2007. Unintended consequences of peacekeeping. Centre for International Political studies. Electronic briefing paper. No 56/2007. University of Pretoria. Available at: http://www.cips.up.ac.za/index.php?ebriefinglist+2089 Accessed 27 October 2009.

Cilliers, J. 1999. Regional African peacekeeping capacity - mythical construct or essential tool? In Cilliers, J. \& Mills, G. 1999 (ed). From peacekeeping to managing complex emergencies: peace support missions in Africa. ISS: Natal Witness. pp.133152. 
Cilliers, J. \& Mills, G. 1999. From peacekeeping to managing complex emergencies: peace support missions in Africa. ISS: Natal Witness. pp.1-7.

De Coning, C. 2004. Towards a common South African peacekeeping system. Center for International Political Studies Electronic Briefing paper no. 16/2004. University of Pretoria. Available at: http://www.cips.up.ac.za/ index.php?ebriefinglist+622 Accessed 27 October 2009.

Docking, T. 2001. Peacekeeping in Africa. Special report no 66. Part one. United States Institute of Peace. Available at: www.usip.org/pubs/specialreports/sr66part1.html Accessed 5 July 2007.

Jooma, M.B. 2006. UN condemns killing of African peacekeepers in Darfur. African Security Analysis Programme, Institute for Security Studies: Pretoria.

Jordan, M.J. 2004. Sex charges haunt UN forces. Christian Science Monitor. November 26, 2004. Available at: http://www.csmonitor.com/2004/1126/p06s02wogi.html. Accessed 5 May 2008.

Kent, V. \& Malan, M. 2003. Decision, decision. South Africa's foray into regional peace operations. Institute for Security Studies. Occasional paper 72. April 2003.

Kent, V. 2005. Peacekeepers as perpetrators of abuse: examining the UN's plans to eliminate and address cases of sexual exploitation and abuse in peacekeeping operations. African Security Review 14(2). pp. 85-92.

Le Roux, L. 2005. The post-apartheid South African military: transforming with the nation. In Rupiya, M. (ed.) Evolutions and revolutions. Institute for Security Studies; Pretoria. pp. 235-266.

Ngoma, N. 2005. Peace support operations and perpetual human failings. African Security Review. Vol 14(2). pp. 1-38.

Ngoma, N. 2004. "Caging the Lions", in Le Roux, L., Rupiya, M., \& Ngoma, N. (eds.) Guarding the guardians. Parliamentary oversight and civil-military relations: the challenges for SADC. pp. 99-108. Institute for Security Studies: Pretoria.

Pepani, C.L. 1999. The role of the state in protecting its population. In Forum. No 2. South African Defence College, Studies in National Security. Pretoria: Joint Staff Course association. August 1999. pp 172-191.

South African Department of Defence. 1996. South African White Paper on Defence. Pretoria: Department of Defence.

South African Department of Defence. 1998. South African Defence Review. Pretoria: Department of Defence. 
South African Department of Foreign Affairs. 1999. White Paper for Participation in International Peace Missions. Pretoria. Department of Foreign Affairs.

United Nations, 2000. United Nations Report on International Peace missions Reform or "Brahimi Report". Available at: http://www.globalpolicy.org.security/ peacekpg/reform/index/htlm Accessed 13 September 2006.

Swigert, J.W. 2004. Challenges of peacekeeping in Africa. Statement before the Africa Subcommittee of the House International Relations Committee, Washington, DC. US Department of State.

Twum-Danso, A. 2003. An overview of child soldiering. Africa's young soldiers; the cooption of childhood. Institute for Security Studies Monograph. No 83. April 2003.

Van der Merwe, S. 2008. Opening remarks by Minister Sue van der Merwe at the seminar of special representatives and envoys dealing with Burundi: Cape Town 22 February 2008. Department of Foreign Affairs. Available at: http://www.dfa.gov.za Accessed 12 May 2008.

Williams, R. 1996. Practical challenges to South African peace operations. Institute of Defence Policy. Available at http://www.iss.co.za/Pubs/Books/ PKVol1/7Williams.pdf Accessed 27 October 2009.

Williams, R. 1999. Challenges for South and Southern Africa: towards nonconsensual peace missions. In Cilliers, J. \& Mills. G. From peacekeeping to complex emergencies; peace support missions in Africa. ISS. Natal Witness. pp. 153-174. 